\title{
Ética e genética: a moral da medicina genética corretiva
}

\author{
Ethics and genetics: \\ the morals of corrective genetic medicine
}

*Lincoln Frias

\begin{abstract}
Resumo: O artigo organiza o debate sobre a medicina genética corretiva (as intervenções genéticas em seres humanos) e analisa as principais objeções contra ela: (1) a acusação de eugenia e (2) a possibilidade do aumento da discriminação e da desigualdade social. A primeira objeção é respondida através da distinção entre eugenia liberal e eugenia autoritária e da crítica à distinção entre terapia e melhoramento. À segunda objeção é oferecida a resposta liberal através da discussão de seus princípios de justiça genética. Portanto, as principais questões morais em torno da medicina genética corretiva são: (a) as intervenções genéticas ameaçam a comunidade moral? e (b) como evitar as consequências sociais indesejáveis das intervenções genéticas? Embora o respeito à autonomia da futura criança e o interesse pela justiça social coloquem limites éticos a esse tipo de intervenção, a conclusão é que a medicina genética corretiva não deve ser proibida.
\end{abstract}

Palavras-chave: eugenia, genética, justiça, medicina, melhoramento, terapia

\begin{abstract}
This paper sorts out the debate about corrective genetic medicine (the genetic interventions in human beings) and analyses the main objections against i: (1) the accusation of eugenics and (2) the possibility of increasing discrimination and social inequality. The first objection was answered by means of the distinction between authoritarian and liberal eugenics and by the criticism of the distinction between therapy and enhancement. To the second objection was provided the liberal answer by means of the discussion of the principles of genetic justice. Therefore, the main moral questions about corrective genetic medicine are: (a) do genetic interventions threaten the moral
\end{abstract}

* Professor de Bioética e Ética Aplicada; Pesquisador CNPq/PNPD, UFMG (Belo Horizonte, Brasil) /Oxford (Oxford, Inglaterra). E-mail: lincolnfrias@gmail.com. Endereço postal: Departamento de Filosofia - UFMG, Faculdade de Filosofia e Ciências Humanas. Av. Antônio Carlos, 6627, Cidade Universitária, $4^{\circ}$ andar, sala 4051, Belo Horizonte, MG - CEP 31270-901.

\begin{tabular}{|l|l|l|l|l|l|}
\hline Veritas & Porto Alegre & v. 58 & n. 1 & jan./abr. 2013 & p. 99-117 \\
\hline
\end{tabular}


community? and (b) how to avoid the undesirable social consequences of genetic interventions? Although the respect for the future child's autonomy and the interest in social justice puts ethical limits on this kind of intervention, the conclusion was that the corrective genetic medicine should not be forbidden .

Keywords: enhancement, eugenics, genetics, justice, medicine, therapy.

Desde as teorias darwinianas sobre a evolução das espécies resultante da seleção natural e o desenvolvimento da genética mendeliana até a descoberta da estrutura da molécula de DNA e o sequenciamento de genomas, a biologia motivou sucessivos questionamentos dos fundamentos de nossa visão do mundo. Desde os anatomistas do século XIV e dos fisiologistas do século XVII, de The Descent of Men até a genômica funcional e as pesquisas com células-tronco embrionárias humanas, a biologia empreendeu/motivou questionamentos sobre os fundamentos de nossa visão do homem.

Tais questionamentos, porém, se tornam presentes à sociedade em geral especialmente quando resultam em tecnologia médica, especialmente através da invenção de fármacos (inclusive vacinas, antibióticos, anestesias, psicotrópicos, anticoncepcionais etc.), que alteram significativamente a fisiologia humana, e de intervenções cirúrgicas agressivas (transplantes, hemodiálise, transfusão de sangue, próteses etc.), que artificializam o corpo humano. No entanto, esses questionamentos tornaram-se urgentes quando os avanços em tecnologia médica chegaram à reprodução humana através de técnicas de reprodução assistida (fertilização in vitro, inseminação artificial, barrigas-de-aluguel, descarte seletivo de embrióes etc.).

Assim como desde as teorias hipocráticas sobre o sêmen, os médicos estudam a reprodução humana; desde Anaxágoras e De Generatione Animalium de Aristóteles, os filósofos discutem o assunto. Contudo, os questionamentos assumem ainda mais radicalidade quando está em questão não a intervenção no corpo de determinado indivíduo, mas a própria hereditariedade e seus mecanismos. A partir da criação e do desenvolvimento da Bioquímica, da Biologia Molecular e da Genética Evolutiva, nos últimos 150 anos, a chamada tecnologia biomédica adquiriu um poderio de intervenção tão radical sobre o ser humano que, em princípio, seu objeto não é mais um paciente ou um grupo de pacientes, mas a própria espécie humana - como ficou evidente no Projeto Genoma Humano.

Assim, se a medicina antigamente resumia-se à medicina paliativa e, modernamente, tornou-se também preventiva; no século $\mathrm{XX}$, surgiu 
a medicina regenerativa e, agora, vivemos os primórdios da medicina genética corretiva. Terminada a parte mais significativa do sequenciamento do genoma humano (genômica estrutural), parte-se à genômica funcional (proteoma e transcriptoma) com um arcabouço científico e técnico mais eficiente para compreender tanto o funcionamento doentio quanto o funcionamento saudável do organismo humano. Aliado ao trabalho com células-tronco, clonagem terapêutica e diagnóstico genético préimplantação, isso possibilita o aparecimento da terapia genética, quer dizer, a intervenção no genoma individual - a "engenharia genética". Para os mais confiantes nesses desenvolvimentos científicos, isso implicaria assumir o surgimento de um estágio pós-evolutivo, ou seja, uma época em que não estivéssemos mais sujeitos à transmissão da hereditariedade através da seleção natural, segundo a melhor adaptabilidade ao meio ambiente de mutações surgidas ao acaso, mas através da seleção consciente e artificial a partir de modificações surgidas de escolhas deliberadas.

Essas intervenções são feitas em células germinativas ou somáticas. Qualquer modificação na linha germinativa (gametócito, esperma, óvulo e zigoto) será hereditária e surtirá efeito na medida em que dará origem a todos os outros tecidos - essas modificações são conhecidas como terapia genética para reprodução, pois modificam um ser humano futuro. Por outro lado, a intervenção em células somáticas é feita em pacientes já nascidos e para ser efetiva deve ser realizada em célulastronco (estaminais), pois elas ainda possuem a capacidade de se dividir, diferenciando-se, isto é, dando origem a células de outros tecidos do corpo e transmitindo às células resultantes seu material genético. Essas células podem ser de três tipos: adultas, embrionárias e préembrionárias. As células-tronco extraídas dos pré-embriões (blastófilo) podem transformar-se em qualquer um dos duzentos tipos de células do corpo humano (totipotentes). Aquelas retiradas do embrião já começam a se limitar, mas ainda podem diferenciar-se em diversos tipos celulares (pluripotentes). E as adultas são ainda mais limitadas, pois geram apenas algumas linhagens de tecidos específicos (multipotentes). A terapia genética não-reprodutiva é a utilização destes vários tipos de células-tronco associadas à clonagem terapêutica ${ }^{1}$ para produção de células geneticamente modificadas do próprio paciente, as quais serão

A diferença entre a clonagem terapêutica e a clonagem reprodutiva é que a primeira é a replicação artificial de células do próprio paciente sem fins reprodutivos, com o objetivo de desenvolver tecidos a partir de células do próprio paciente para evitar rejeição e satisfazer a demanda por transplantes. A segunda é o desenvolvimento de um embrião genotipicamente idêntico a um doador - mas, tal como com gêmeos univitelinos, sem garantia de fenótipo idêntico. 
reimplantadas nele mesmo, para corrigir algum problema fisiológico (tumores, queimaduras, deficiência protéica, enzimática, vitamínica ou hormonal).

\section{O debate filosófico sobre as intervenções genéticas}

Os meios de comunicação acompanharam de perto esses avanços mas, não poucas vezes, dando por certo o que ainda era incerto e como próximo o que os próprios cientistas mal vislumbravam. Ligada aos meios de comunicação começa a ocorrer a reflexão sobre o assunto, por jornalistas, cientistas, teólogos, médicos, ativistas e políticos, principalmente a partir da segunda metade da década de oitenta, à medida que a capacidade médico-científica sofistica-se, aparece a necessidade de regulamentação e construção de diretrizes governamentais em relação à saúde, justiça, planejamento, ciência e tecnologia a respeito das intervenções genéticas. Nesse momento, juntamente com as manifestações das organizações internacionais (ONU-UNESCO, UE, Igrejas, ONGs etc.), importantes filósofos acercam-se do debate - p.ex., Ronald Dworkin, Jürgen Habermas, Philip Kitcher e Francis Fukuyama; antecedidos pelos especialistas em bioética: Allen Buchanan, Nicholas Agar, Julian Savulescu, Peter Singer, Jonathan Glover, Leon Kass, Axel Kahn etc.

Esse debate é composto por uma grande quantidade de questões, as quais podem ser organizadas em torno dos seguintes problemas, sem pretensão de exaustividade:

i. Problema da Pesquisa: testes de técnicas de intervenção genética em adultos devem ser realizados quando não há tratamento possível? E em fetos e embriões? A pesquisa com célulastronco embrionárias deve ser permitida? $\mathrm{E}$ a clonagem terapêutica? Etc.

ii. Problema dos Organismos Geneticamente Modificados: temos o direito de interferir na estrutura dos organismos (vegetais, animais e bactérias)? Organismos geneticamente modificados podem aumentar a dependência dos países subdesenvolvidos? Etc.

iii. Problema da Propriedade Intelectual: É possível haver um proprietário de genes e outras parcelas de DNA (ou proteínas ou RNA)? Se sim, quem tem o direito? Como deve acontecer a participação das empresas privadas no patenteamento das biotecnologias genéticas, gênicas e genômicas?

iv. Problema da Liberdade: genes são responsáveis pelo comportamento das pessoas? Há implicações quanto à responsabilidade moral e legal dos agentes nas descobertas genéticas? 
v. Problema da Reprodução: quanto os pais devem poder decidir na reprodução assistida? Como isso pode afetar o futuro da criança? Como distinguir entre terapia e melhoramento?

vi. Problema da Desigualdade: como a informação genética pessoal afetará a percepção social e individual das pessoas? E das comunidades minoritárias? A intervenção genética é uma ferramenta ou um empecilho à justiça distributiva? Sua liberação aumentará a desigualdade social?

vii. Problema da Privacidade: quem deve ter acesso à informação genética pessoal? Estado, seguradoras, empregadores, tribunais, escolas, agências de adoção, militares, polícia etc.?

O problema da reprodução será nosso foco, por concentrar as dificuldades da problemática. Para tratá-lo, porém, trataremos dos problemas da pesquisa, da desigualdade e da privacidade; pois o primeiro condiciona-o e os dois últimos são suas possíveis consequências.

Mesmo nos restringindo ao problema da reprodução, o espectro de posições no debate é bastante variado. ${ }^{2}$ Contudo, pode-se dizer que há os oponentes radicais, ${ }^{3}$ os oponentes moderados, ${ }^{4}$ os defensores moderados ${ }^{5}$ e os defensores radicais. ${ }^{6}$ Os oponentes radicais baseiam-se,

2 Uma primeira evidência desse debate é que os pensadores lidam com cenários bastante diferentes de acordo com o poder de intervenção que julgam que a genética molecular possuirá a médio ou a longo-prazo. De modo que eles podem ser distribuídos em uma linha contínua cujos dois extremos são os precavidos e os reticentes: os primeiros concedem hipoteticamente poderes máximos à genética molecular, pois "[e]ntre o que é ficção científica e possibilidade científica a médio-prazo, aprendemos que é melhor não apostar. Antes ter princípios que sirvam para situações impossíveis do que nenhum princípio para uma situação repentina" (AGAR, 2004: 172 - trad. nossa). Enquanto que o segundo grupo prefere lidar com o futuro científico já vislumbrado; pois se atualmente já somos capazes de efetuar mais de 600 testes genéticos em embriões sobre doenças específicas (e essa capacidade tem um prospecto de crescimento bastante favorável) é muito menos certo, porém, que esse reconhecimento da associação de uma determinada seqüência genética a uma doença se traduza imediatamente em cura para essas doenças, pois a parte mais difícil não é o seqüenciamento, mas o controle sobre todos os componentes da expressão gênica, a invenção de processos eficientes de silenciamento, adição e repetição de determinadas e complexas seqüências de nucleotídeos para produzir (ou não) determinada proteína responsável por determinado aspecto anatômico ou função fisiológica do corpo humano (Cf. HITCHER, 2002). Embora nos coloquemos junto aos reticentes, pretendemos dar respostas aos precavidos; portanto, assumiremos para os fins da discussão que teremos em breve alguns poderes consideráveis de intervenção genética.

3 JOÃO PAULO II, 1995; KASS, 2002; FUKUYAMA, 2002; ANNAS, 2004 etc..

4 JONAS, 1979; HABERMAS, 2001.

5 RAWLS, 1971; DWORKIN, 1999; BUCHANAN et al.; KITCHER, 2002; SINGER, 1993, 2003; 2000; AGAR, 1999.

6 NOZICK, 1974; STOCK, 2002; além dos autores conhecidos como transhumanistas ou pós-humanistas. 
na maioria das vezes, em argumentos religiosos; não trataremos deles aqui, pois caso o argumento dependa das crenças não racionalmente motivadas peculiares a esse grupo, não pode servir de embasamento para políticas públicas e decisões éticas universalizáveis em uma sociedade democrática pluralista. Os defensores radicais também serão preteridos em nossa discussão, uma vez que lidam com cenários ainda cientificamente improváveis, não costumam pensar as implicações políticas de sua posição e não valorizam suficientemente os riscos. Resta-nos a discussão entre os defensores e opositores moderados, definidos como aqueles que tomam sua decisão pautados em argumentos racionais (isto é, publicamente defensáveis com base em razões que tenham valor mais ou menos comum em uma democracia pluralista), que estejam cientificamente informados (discutam quais as reais possibilidades científicas a curto e médio prazo), que levem em conta os riscos biológicos e sociais das manipulações genéticas e estejam atentos às reverberações políticas dos posicionamentos éticos por eles preconizados.

Dentre esses pensadores, os argumentos mais comuns a favor da liberação de intervenções genéticas são os de que ela pode beneficiar:

a) os pacientes, ao prevenir tanto doenças genéticas quanto deficiências e sofrimentos associados a elas;

b) os pacientes, ao proporcionar-lhes os efeitos de melhoramentos de saúde e longevidade;

c) os pais, pois eles têm o direito de prevenir doenças e promover a saúde de seus filhos;

d) os pais com problemas reprodutivos, ao possibilitar-lhes ter filhos saudáveis;

e) a sociedade, ao reduzir os custos sociais e econômicos produzidos por doenças genéticas;

f) a sociedade, na medida em que o melhoramento de humanos pode incrementar-lhes a capacidade cognitiva, produtividade, experiência estética, convivência e outros objetivos sociais;

g) a espécie humana, em seu arcabouço genético, ao possibilitar que genes considerados mais adequados sejam incentivados e genes considerados mais inadequados sejam evitados;

Por outro lado, os argumentos contrários à permissão de intervenções genéticas derivam da crença de que ela pode prejudicar:

a) os pacientes, através de defeitos genéticos decorrentes dela, p.ex.: disfunções protéicas; 
b) os pacientes, na medida em que, posteriormente, eles podem verse como produtos de seus pais ou mercadorias e, assim, terem sua autonomia comprometida ${ }^{7}$. Além de ser uma violação dos direitos da criança de não ser prejudicada, de ter um futuro em aberto e de não ser sujeito de um experimento;

c) as gerações futuras, uma vez que alguns defeitos genéticos podem não se manifestar imediatamente;

d) a sociedade, devido aos custos de pacientes com defeitos genéticos decorrentes dessas intervenções;

e) a sociedade (além de grupos e indivíduos), pois pode criar ou aumentar a discriminação negativa contra determinado(s) grupo(s) e positiva a favor de outro(s), segundo sejam considerados geneticamente bem ou mal providos, prejudicando, em especial, portadores de deficiências físicas e mentais.

g) a sociedade, pois o descarte de embriões necessário em tais técnicas ofende a dignidade humana e, assim, pode colapsar a moral e o Direito;

h) a sociedade, pois aumentará a desigualdade de oportunidade entre pobres e não-pobres;

i) a espécie humana, em seu arcabouço genético, ao reduzir a diversidade genética;

j) a espécie humana, pois não temos o direito de "brincar de Deus" ao intervir na evolução.

Uma vez que a validade dos argumentos contrários a, c e d baseia-se no estado atual das ciências que fundamentam as intervenções genéticas, eles são todos uma forma de argumento do risco. A única conclusão que se segue a esse tipo de argumento é não realizar intervenções genéticas até que elas sejam seguras e eficientes. Isso é concedido por todos os pensadores em questão. A questão ética, porém, permanece intocada: caso torne-se um procedimento seguro e eficiente, há algum impedimento a intervir geneticamente em seres humanos? Por isso, tais argumentos já podem ser recusados.

É possível dividir os argumentos contrários restantes em dois grupos: (1) os argumentos acerca do status humano (b, f e i) - majoritariamente

7 Em geral, quem utiliza esse argumento propõe que haverá restrição da liberdade (1) na medida em que o futuro adulto será incapaz de fazer escolhas livres, pois já estaria determinado pelos genes, (2) na medida em que a intervenção genética limita os comportamentos e planos de vida do paciente e (3) na medida em que aumentam as expectativas e pressões dos pais - além de (4) retirar do agente o mérito de suas conquistas e, especificamente na clonagem, (5) a individualidade do paciente é ameaçada. 
deontológicos e baseados em valores (dignidade humana, natureza humana, sacralidade da vida, inviolabilidade da pessoa); e (2) argumentos de consequências (e, g e h) - majoritariamente utilitaristas e preocupados com os resultados indesejáveis que podem surgir a partir das intervenções genéticas. Segundo estes últimos, as consequências negativas superam os benefícios que ela pode gerar; logo, ela é eticamente inaceitável. Por outro lado, os argumentos deontológicos afirmam que há algo intrinsecamente errado na modificação genética de seres humanos e que ela continuaria eticamente condenável ainda que se mostre que proporcionará mais benefícios do que prejuízos.

\section{O Problema da Eugenia e o Problema da Distinção entre Terapia e Melhoramento}

A maioria das pessoas sente uma repulsa profunda contra a inter venção genética. Essa repulsa é resumida na metáfora "brincar de Deus", que se apresenta de forma privilegiada no tema da eugenia. Critica-se a intervenção genética em humanos através do argumento de que ela seria uma prática sujeita aos mesmos abomináveis erros e censuras das eugenias propostas pelo darwinismo social e pelo nazismo (...), tendendo ao genismo (o preconceito segundo diferenças genéticas) e ao genocídio genético (a destruição de algum grupo geneticamente preterido). ${ }^{9}$

Para dar conta dessa crítica, Nicholas Agar ${ }^{10}$ distingue entre eugenia autoritária e eugenia liberal. Na versão autoritária, a escolha das características segue apenas um ou alguns modelos que são impostos de maneira uniforme pelo Estado, ao passo que, no modelo liberal, a eleição das características seria feita pelos pais e, por isso, tenderia a ser plural, autônoma e livre de modelos impostos. Logo, segundo Agar, a eugenia por si não é ruim, o que é ruim é o autoritarismo a dirigi-la. Portanto, na medida em que a intervenção genética possibilite uma eugenia que aumente a liberdade dos agentes, ao contrário da autoritária que a diminuía, a intervenção genética não estaria sujeita às mesmas críticas e erros que os projetos eugenistas autoritários do começo do século XX.

Porém, como mesmo a concepção liberal da eugenia gera receios, alguns pensadores distinguem entre intervenção genética terapêutica e intervenção genética para melhoramento. A primeira evita fatores indesejáveis, tais como doenças e deficiências, ou seja, permite que o

JONAS, 1979: 61.

9 ANNAS, 2004: 284-5.

10 AGAR, 1999. 
indivíduo aproxime-se do nível de desempenho orgânico considerado normal; ao passo que a segunda favorece fatores desejáveis, tais como aumento da capacidade cognitiva, muscular ou perceptiva, isto é, procura fazer com que o indivíduo disponha de capacidade que ultrapasse o nível considerado normal.

Habermas, por exemplo, distingue entre eugenia negativa (terapia) e eugenia positiva (melhoramento) e, a partir disso, defende uma proteção jurídica baseada no direito a uma herança genética não-manipulada, com a exceção de uma ponderação moral acerca do consenso suposto no caso da eugenia negativa - pois é de se supor que a criança aceitaria de bom grado não ter tal ou qual doença. ${ }^{11}$

Essa distinção é bastante criticada, pois condicionamentos tais como ministrar vitaminas e hormônios, disponibilizar bens de consumo, a escolha da escola etc. são práticas de melhoramento não moralmente diferentes de intervenções genéticas, pois também são criticáveis como intervenções drásticas na constituição física, emocional e cognitiva da criança. O que implica que tanto as intervenções não-genéticas quanto as genéticas devem ser reguladas, mas não simplesmente proibidas. ${ }^{12}$

Uma segunda crítica enfatiza que a distinção entre terapia e melhoramento depende de uma distinção ulterior entre doença e saúde - que, por sua vez, é bastante problemática. ${ }^{13}$ Segundo o critério biológico, sadio é o organismo que está apto a interagir satisfatoriamente com seu ambiente. Ora, essa aptidão varia de acordo com o ambiente. Por exemplo, como dificultavam a relação do indivíduo com o ambiente, canhotismo e homossexualismo já foram considerados patologias. Logo, esse não é um critério seguro para dizer quais intervenções são permissíveis. ${ }^{14}$

O critério social propõe que sadio é aquilo que é normal. Ora, esse critério também é demasiadamente variável para estabelecer a distinção. Por exemplo, sabemos que a altura masculina de $1.40 \mathrm{~m}$ representa alguma patologia. Mas e a de $1.50 \mathrm{~m}$ ? Alterar a estatura de um homem de $1.70 \mathrm{~m}$ a $1.90 \mathrm{~m}$ é melhoramento; mas e de $1.50 \mathrm{~m}$ a $1.65 \mathrm{~m}$ ? O mesmo vale para o caso de quocientes de inteligência, por exemplo. ${ }^{15}$ Logo, dado que não há consenso acerca da distinção entre normalidade e anormalidade, não pode haver também no que toca à saúde e doença e, muito menos, entre terapia e melhoramento. Ou, pelo menos, essa distinção não é tão natural e óbvia como parece a alguns.

11 HABERMAS, 2001: 26-7.

12 AGAR, 1999: 172.

13 KITCHER, 2002: 233; cf. HARE, 1993: 31-47.

14 Em outra versão desse critério, a distinção é entre processos biológicos mórbidos e não-mórbidos. Contudo, ela está sujeita a dois contraexemplos, a menstruação e o parto - dois processos mórbidos que não são considerados doentios.

15 Cf. SINGER, 2003. 


\section{A objeção de Habermas e a crítica ao determinismo}

Ao criticar Agar, Habermas diz que "o fenômeno inquietante é o desvanecimento dos limites entre a natureza que somos e a disposição orgânica que nos damos" (2001: 32). De maneira que o problema que lhe interessa não é o melhoramento em si, mas o efeito dominó (Dammbruch, slippery slope) até intervenções que cruzem a linha da espécie. Propondo que a biotecnologia humana desafia a distinção entre "o que cresceu naturalmente" e "o que foi fabricado", pois, nela, um sujeito faz de outro sujeito um objeto, diz que essa "instrumentalização da espécie" ameaça nossa autocompreensão como seres morais na medida em que solapa a suposta igualdade entre pais e filhos. É o que ele chama de "argumento da heterodeterminação": a intervenção genética torna o genoma artificial quando "introduz uma intenção no genoma da futura criança". Aquele que surgir dessa intervenção não se reconhecerá como "autor de sua própria vida", caso não concorde com as intenções fixadas em seu genoma, faltar-lhe-ão, então, a liberdade e autonomia, os atributos essenciais para participar da comunidade moral. ${ }^{16}$

Segundo Habermas, é justamente a pertença a essa comunidade moral que é a dignidade humana ${ }^{17}$ e a própria natureza humana. $\mathrm{Na}$ medida em que as intervenções genéticas ameaçam essa dignidade ao impedir a pertença à comunidade, elas ameaçam a própria natureza humana. Por isso, Habermas defende que faz parte de nossa espécie, de nossa natureza, sermos sujeitos ao acaso; portanto, deveríamos manter a identidade da espécie através de uma "moralização da natureza humana" feita por uma "ética da espécie" por meio da decisão pela "indisponibilidade do genoma humano para fins de eugenia positiva" e da proibição do uso (e descarte) de embriões para pesquisa e do diagnóstico genético pré-implantação - pois esses procedimentos podem levar à eugenia liberal.

O ponto central dessa objeção habermasiana é a presunção de que a intervenção genética solape a dignidade humana ao tolher a liberdade e autonomia dos filho ${ }^{18}$ - uma forma do argumento contrário (b).

16 Segundo tal visão, essa eugenia não é tão liberal, pois o acréscimo de liberdade diz respeito apenas aos pais - que serão livres para "controlar o destino dos filhos"; em contrapartida, os filhos terão um decréscimo de liberdade ao terem seus planos de vida possíveis limitados.

17 Essa concepção kantiana de dignidade humana ainda tem tal influência que parece ser a mesma que aparece 14 vezes nas cinco páginas da Universal Declaration on the Human Genome and Human Rights da UNESCO (1997).

18 Essa tese de Habermas, porém, é criticável a partir de, pelo menos, outros três pontos: (1) da concepção de natureza humana defendida, (2) do status normativo concedido à espécie humana e (3) da distinção entre terapia (eugenia negativa) e melhoramento 
A deficiência deste argumento é pressupor que as intervenções genéticas são determinantes. O determinismo genético é essa crença de que genes (genótipos) causam necessariamente características (fenótipos). Uma perspectiva biologicamente mais informada mostra que o embrião que sofreu intervenção genética não nasce com uma trajetória prédeterminada. Estudos biológicos demonstram que podemos diferenciar três tipos de determinismo genético: ${ }^{19}$ (a) forte: o gene G quase sempre implica o desenvolvimento da característica C (em 95\% ou mais); (b) moderado: na maior parte das vezes G implica C (acima de 50\%); (c) fraco: $\mathrm{G}$ algumas vezes leva ao desenvolvimento de $\mathrm{C}$ (embora $\mathrm{G}$ aumente a probabilidade de $\mathrm{C}$, ela é menor do que 50\%) - G está associado a C, mas não é determinante.

Embora muitos autores discutam as intervenções genéticas pressupondo o determinismo genético, o que a moderna genética oferecenos é em grande parte o determinismo genético fraco, e, em menor medida, o determinismo genético moderado. Quer dizer, na maioria das vezes, determinados genes são razões necessárias, mas não suficientes, para determinado fenótipo, pois, na passagem do genótipo ao fenótipo, há dois fatores com forte taxa de interferência, quais sejam: a epigenia (o desenvolvimento celular) e o ambiente. No desenvolvimento celular, vários fatores interagem interferindo na expressão de um gene específico, desde a relação com outros genes até erros de funcionamento - p. ex., há características multigênicas, aquelas que dependem da combinação de vários (até milhares) de genes para se expressar. Acrescentemos a isso o ambiente preenchendo ativamente o intervalo entre genótipo e fenótipo, incluindo desde as necessidades nutricionais até exercícios físicos e mentais para desenvolver tendências genéticas, o que permite concluir que o arcabouço genômico fornece apenas maiores ou menores possibilidades de desenvolvimento de características, não certezas. Devemos, portanto, raciocinar a partir de relações causais probabilísticas. $\mathrm{Na}$ melhor das hipóteses, pais poderão disponibilizar aos filhos um

(eugenia positiva) - discutida acima. Aqui e em outros momentos, Habermas condiciona a pertença à comunidade moral à pertença à espécie, recusando a diferença entre homo sapiens (corpo) e pessoa (Cf. SINGER, 1993: 85-7, 150-6). Isso é apenas o começo da desavença entre a ética da espécie de Habermas e o anti-especismo defendido por Singer. Acerca do primeiro ponto, (FENTON, 2006: 35-42) aponta como quatro fragilidades da concepção habermasiana de natureza humana, ou de "o que significa ser humano", as pressuposições: (1) de que ela é definível; (2) de que ela é natural, isto é, ainda não sofreu interferência da tecnologia; (3) de que há uma divisão clara entre o que é natural e o que não é; e (4) de que essa linha marca uma diferença moral. (BAILLIE e CASEY, 2004) organizaram uma boa discussão multidisciplinar sobre a obsolescência ou não do conceito de natureza humana.

19 RESNIK e VORHAUS, 2006. 
genoma propenso à inteligência supranormal, ao desenvolvimento muscular avantajado ou de dotes musicais excepcionais etc.; contudo, a expressão de tais características dependerá do exercício por parte do próprio indivíduo.

Há, porém, algumas características com determinismo forte, por exemplo, a cor dos olhos e o sexo. Logo, pode ser que existam outras e que, assim, ofereçam ameaça à liberdade da futura pessoa. Uma resposta interessante é dada por Agar, no próprio artigo que Habermas critica. Ele propõe que, nas intervenções terapêuticas ou para melhoramento, os pais devem escolher - ou a legislação deve permitir que os pais escolham - apenas as características que impediriam os piores planos de vida, não que escolhessem o que julgam os melhores plano de vida. É "o máximo constrangimento na escolha do plano de vida", de maneira que o melhoramento deve ser feito sob um véu de ignorância rawlsiano. A escolha sobre quais características incentivar e quais prejudicar deve ser feita ignorando planos de vida específicos, almejando apenas a qualidade de vida em geral. ${ }^{20}$ Deste modo, sim, aumenta-se a liberdade do futuro indivíduo, pois ele supostamente não estará sujeito, por exemplo, a defeitos genéticos que limitem sua capacidade motora, imunológica e cognitiva. Se pudermos ter vidas mais saudáveis, mais imunidade e longevidade, seremos mais autônomos e mais livres.

Mas o argumento habermasiano tem ainda outro aspecto: a pessoa pode sentir-se estranha às intenções fixadas em seu genoma. Os atuais filhos do acaso genético podem renegar as preferências dos pais, os futuros filhos da escolha genética supostamente não, pois a escolha estaria inscrita em seu genoma. E desse modo estaria destruída a igualdade moral, que é o fundamento da comunidade moral e dos direitos humanos, tornando a relação entre pais e filhos assimétrica, pois estes seriam um produto daqueles.

Nossa argumentação contra o determinismo genético mostrou porque a intervenção genética não torna o filho um produto dos pais e a limitação à intervenção para um plano de vida geral esvazia ainda mais essa ideia de produto. A essas duas contra-argumentações acrescentam-se outras duas. A primeira, que não desenvolveremos, é a pergunta: na medida em que comporta forte centralização do poder, as posições de paternidade e maternidade já não são, por definição, assimétricas em relação aos filhos?

Uma segunda contra-argumentação é mostrar que apenas por meio da intervenção genética é que se estabeleceria a simetria moral entre pais e filhos, na medida em que ela concederia ao filho (e, em última instância, à sociedade) o direito de exigir dos pais justificativas para

20 Cf. AGAR, 1999: 179. 
as escolhas que fizeram sobre seu genoma. ${ }^{21} \mathrm{~A}$ intervenção genética ao invés de destruir a comunidade moral a fortalecerá, pois tornará passível de justificação, de responsabilização, o código genético de alguém, algo que, atualmente, está fora do âmbito de controle. Surgem questões morais como: pais que sabem que transmitirão propensão à miopia, a cardiopatias ou propensão a vícios são moralmente condenáveis? E os que não sabem? E os que poderiam saber e preferiram não saber? Seremos moralmente obrigados a não ter filhos com desvantagens genéticas que gerem menos oportunidades e mais sofrimento físico ou emocional? Pais serão responsabilizados pela existência de crianças com qualquer tipo de qualidade ou habilidade abaixo do normal? Como fica o status dos deficientes? Enfim, seremos obrigados a evitar ter filhos anormais, a apenas ter filhos normais ou a ter filhos com qualidade supranormais, ou seja, com qualidade genômica ótima?

Essas possíveis reorganizações de nossas referências morais é que preocupam Dworkin, para quem a passagem do acaso à escolha não necessariamente ofende nossos valores presentes, mas pode torná-los obsoletos, pois nossa identidade genética tem sido um paradigma da responsabilidade da natureza e não nossa, mudar isso desestabilizaria nossa moralidade. Para ele, é isso que significa "brincar de Deus": não o medo de fazer algo errado, mas perder a capacidade de distinguir entre certo e errado. ${ }^{22}$ As intervenções genéticas ameaçam toda uma forma de vida: aquela baseada na moralidade e na liberdade de ser responsabilizado por sua própria vida, a autonomia. Ser livre, Habermas propõe,${ }^{23}$ é ter um passado antes de seu passado que não esteja sujeito à vontade de alguém. Esse passado era natural, quer dizer, não intencional, "fruto do acaso", "loteria genética". Com as intervenções genéticas, ainda que não pressuponhamos o determinismo genético nem limitemos nossos filhos a planos de vida específicos, inseriremos uma séria modificação em nossa forma de vida: colocar-nos de fora da evolução natural, controlar o processo evolutivo do próprio organismo que somos, da própria espécie a que pertencemos.

\section{Genética e justiça social}

O que Habermas chama de "inserção da moral em uma ética da espécie humana" é essa decisão sobre instrumentalizar ou não nosso genoma, passar ou não à época pós-evolutiva, passar ou não do acaso à escolha, pois corrigir geneticamente a si mesmo e fazer escolhas

21 FELIPE, 2005: 353.

22 DWORKIN, 1999.

23 Cf. HABERMAS, 2001: 75 e 83-4. 
genéticas para um filho (ou uma população) são problemas diferentes. Os pais já são responsáveis pelo fato de seu filho nascer; e propusemos que também devem ser responsáveis pela sua condição. Mas devemos também ser responsáveis pela condição de todos os seres humanos que nascerem daqui em diante? Esta resposta exige mais ponderações, pois quando deslocamos o foco das questões genéticas do plano individual para o coletivo, os problemas são de natureza diferente. Por exemplo, a possível utilização de informações genéticas por organizações governamentais, empregadores, polícia e seguradoras pode criar ou aumentar a discriminação negativa contra determinado(s) grupo(s) e positiva a favor de outro(s) - como vislumbrado pela objeção (e).

Chega-se à objeção $(g)$, segundo a qual a utilização de intervenções genéticas prejudicará "a sociedade, pois aumentará a desigualdade de oportunidade entre pobres e não-pobres". Terapias genéticas serão dispendiosas, muito provavelmente os mais desprovidos economicamente não terão acesso a elas. Logo, isso implica que a quem já possui a vantagem econômica será concedida também a vantagem genética? Ou o governo deverá arcar com enormes e onerosos programas públicos de terapia genética, preterindo outras formas de tratamento?

Caso a liberação de algumas terapias genéticas aumente seriamente a injustiça social, isso será suficiente para proibi-las, pois poderia criar uma classe biologicamente superior, na qual concentraria o poder político e as vantagens sociais, como vislumbrado no livro Admirável Mundo Novo e no filme Gattaca . Pois bem, como utilizá-las sem consequências ético-políticas perniciosas?

Os conservadores optam por proibir a utilização de terapias genéticas herdáveis. ${ }^{24,25}$ Os libertários propõem a ideia de um "supermercado genético", diluindo as novas responsabilidades em um mercado sem regulação estatal. ${ }^{26} \mathrm{E}$ os liberais sugerem que o Estado aceite a responsabilidade advinda da passagem do acaso à escolha. ${ }^{27}$

${ }_{24}$ FUKUYAMA, 2002; KASS, 2002.

25 Os filósofos mais influentes do President's Council on Bioethics do governo George W. Bush.

${ }^{26}$ NOZICK, 1974: 315, nota; SINGER, 2003.

27 RAWLS, 1971; BUCHANAN et al., 2000; DWORKIN, 1999. O que Rawls diz sobre eugenia serve à nossa questão: "uma vez que se aceita o princípio da diferença, as maiores habilidades são consideradas como um bem social a ser usado para o bem comum. Mas também é do interesse de cada um ter maiores dotes naturais (...). Na posição original, então, as partes querem assegurar para seus descendentes a melhor dotação genética (pressupondo que a sua própria seja fixa). A busca de políticas razoáveis com respeito a isso é algo que as gerações anteriores devem às posteriores. Assim, ao longo do tempo, uma sociedade deve tomar atitudes para pelo menos preservar o nível geral de capacidades naturais e impedir a difusão de defeitos graves. Essas medidas devem ser guiadas por princípios com os quais as partes estariam dispostas a concordar 
Uma vez que, como vimos, não há justificativa moral para impedir completamente as intervenções genéticas, a posição conservadora tornase insustentável. E dado que, especialmente em países periféricos, a liberação das intervenções genéticas agravará a desigualdade social, o libertarismo deve ser recusado.

Portanto, a posição liberal é a mais adequada, tratando a disponibilização das intervenções genéticas como um tema em justiça distributiva, o que traz consigo a seguinte questão: qual o modo de distribuição do acesso a intervenções genéticas é mais justo? Há três respostas principais: (a) o princípio da igualdade genética, baseado no igualitarismo puro (pure egalitarianism), que procura fornecer a todos as mesmas oportunidades de intervenção genética; (b) o princípio do mínimo genético decente (genetic decent minimum), baseado no suficientismo (sufficitarianism), que pretende conceder a todos apenas o considerado necessário para uma vida digna; e (c) o princípio da diferença genética, baseado no prioritarismo (prioritarianism) que propõe que a ajuda aos mais necessitados é mais importante do que a ajuda aos mais satisfeitos. Eles podem ser assim diferenciados: ${ }^{28}$

- Igualitarismo: a igualdade tem valor moral por si mesma.

- Suficientismo: o que é moralmente importante é que todos tenham o suficiente.

- Prioritarismo: o que é moralmente importante é beneficiar as pessoas em pior situação.

Igualitaristas propõem que todos devem ter acesso às mesmas intervenções, se isso não prejudicar a realização de outros valores importantes (p.ex., liberdade e utilidade). Já os suficientistas não tomam a igualdade como um valor, preocupam-se apenas com que todos tenham acesso a um certo mínimo. Por exemplo, um nível que lhes permita viver uma vida dentro do funcionamento normal. O justo é que todos tenham esse mínimo, não importa se uma minoria tem muito mais que esse mínimo ou se apenas uma minoria tem somente esse mínimo. Para eles, que exista desigualdade é moralmente irrelevante.

para o bem de seus sucessores" (RAWLS, 1971: 115). E páginas adiante acrescenta: “Também existe, pelo menos teoricamente, a questão de uma política genética razoável. Nesses casos, a fim de levarem adiante a idéia da posição original, as partes não devem conhecer as contingências que as colocam em oposição. Elas devem escolher princípios cujas consequências estão preparadas para aceitar, não importando a geração a qual pertençam" (Ibid., 147).

28 PARFIT, 1996. 
O prioritarismo afirma que devemos nos preocupar mais com os que estão em pior situação (não importa se a pior situação está muito acima do mínimo). Quanto pior os piores estiverem, mais urgente é ajudá-los. $\mathrm{O}$ acesso às intervenções genéticas deve ser distribuído priorizando os menos favorecidos geneticamente, aqueles que têm mais necessidade de tratamento, não importando se isso não levar à igualdade e nem se isso está acima do mínimo genético decente.

O princípio de igualdade genética não é uma boa opção, porque (1) implica gastos governamentais insustentáveis - além de poder servir a algum projeto eugênico autoritário e a uma homogenização da espécie (objeção h); e (2) exige que se impeça os que estão em uma situação econômica melhor de usar intervenções genéticas que não estejam disponíveis a todos - o que é uma ofensa à sua liberdade.

Por sua vez, o princípio do mínimo genético decente, apesar de mais interessante, também deve ser preterido, pois permite que exista muita desigualdade, o que pode criar inveja social e minar a cooperação social.

O princípio da diferença genética parece o mais adequado, pois (1) sempre direcionará esforços para os que estiverem em pior situação, então, atingirá o mínimo decente (e o superará, na medida do possível); e (2) apesar de ainda ofender o direito dos pais em melhor situação, não o faz de forma tão grave quanto o igualitarismo.

Mas o princípio da diferença genética deixa três importantes questões em aberto: como estabelecer os merecedores de prioridade (problema do peso), o que significa essa prioridade e quanta prioridade deve ser dada (problema do objeto). O problema do peso trata do valor adequado que uma teoria da justiça deve atribuir aos geneticamente desavantajados em oposição a outros desavantajados (pobres, vítimas de acidentes etc.) e aos não-desavantajados. O problema do objeto trata da lista de vantagens/desvantagens genéticas que devem ser incluídas em uma abordagem das demandas da justiça distributiva. ${ }^{29}$ Quer dizer, dadas as restrições orçamentárias, quais são as condições que deverão ser incluídas na cobertura pública? Apenas condições que afetam gravemente a qualidade de vida e restringem as oportunidades (disposições à má-formação, anomalias cromossômicas, doenças degenerativas etc.)? Ou, além dessas, devem ser cobertas condições menos graves e limitadoras (obesidade, propensões a problemas cardíacos, respiratórios e imunológicos etc.)? Ou a cobertura deve ser ainda mais abrangente e incluir, além desses dois grupos, condições não patológicas (sexo, altura, capacidades cognitivas, desenvolvimento muscular etc.)?

${ }^{29}$ FARRELY, 2004. 
Uma resposta possível é que a cobertura pública atinja as condições mais graves para todos e, para os economicamente menos favorecidos, as graves e médias. Mas isso já incluiria uma decisão sobre o problema do peso ao relacionar a desigualdade genética com a desigualdade de renda. Entretanto, esses desenvolvimentos são complexos demais para serem feitos nesse trabalho.

Qualquer que seja, a resposta deverá equilibrar a liberdade reprodutiva com a necessidade de promover a igualdade de oportunidades entre naturalmente geneticamente prejudicados e beneficiados e assim fomentar a justiça genética (intra e intergeracional).

\section{Comentários finais}

Neste trabalho, oferecemos um esclarecimento da problemática em torno da medicina genética corretiva, as intervenções genéticas em seres humanos, concentrada no problema da reprodução. Para tanto, abordamos as questões da natureza humana e da eugenia e discutimos as distinções entre intervenções genéticas hereditárias e nãohereditárias e entre terapia e melhoramento. Isso forneceu elementos para articular as duas questões principais: (1) as intervenções genéticas ameaçam a comunidade moral?; e (2) como evitar consequências sociais indesejáveis das intervenções genéticas? $\mathrm{E}$, a partir dessa segunda questão, apresentamos o princípio da diferença genética como o melhor princípio de justiça para lidar com o problema da desigualdade.

A conclusão é que não há argumentos éticos aceitáveis para impedir completamente as intervenções genéticas em seres humanos, mesmo intervenções genéticas hereditárias para melhoramento; no entanto, o respeito à liberdade da futura criança e o interesse em promover a justiça social colocam limites éticos para essa intervenção. A indicação de quais são esses limites éticos surge das respostas que se dê às questões (1) e (2). Nossas respostas foram que as intervenções genéticas não ameaçam a comunidade moral, mas a incrementa, na medida em que torna os pais responsáveis pelo genótipo dos filhos; e que o princípio da diferença genética é a melhor maneira de evitar consequências indesejáveis.

Entretanto, essas respostas são incompletas, pois lhes falta um tratamento da questão de como proteger grupos vulneráveis (portadores de deficiência, grupos étnicos etc.) e de quais características os pais serão obrigados a garantir a seus filhos (se é que haverá alguma), quais serão proibidos a transmitir (se é que haverá alguma) e quais serão opcionais. 


\section{Referências}

AGAR, Nicholas. "Liberal Eugenics". In: SINGER, Peter; KUHSE, Helga (Orgs.). A Companion to Bioethics. Oxford: Blackwell, 1999, p. 171-81.

ANNAS, George J. "Genism, Racism and the Prospect of Genetic Genocide". In: BINDÉ. Jérôme (Org.). The Future of Values: 21st-century Talks. Paris/New York: UNESCO Publishing/Berghahn Books, 2004.

BAILLIE H. W.; CASEY T. K. (Orgs.). Is Human Nature Obsolete? Genetics, Bioengineering, and the Future of the Human Condition. Cambridge: MIT Press, 2004.

BUCHANAN, Allen; BROCK, Dan W.; DANIELS, Norman; WIKLER, Daniel. From Chance to Choice: Genetics and Justice. Cambridge: Cambridge University Press, 2000 .

DWORKIN, Ronald. "Justice and Fate: an introductory paper to genetics, identity and justice". <http://www.21stcenturytrust.org/genetics.doc >, acessado em: 20.02.2007.

FARRELLY, Colin. The Genetic Difference Principle. The American Journal of Bioethics, 4(2), 2004, p. 21-28.

FELIPE, Sônia T. “Equívocos da Crítica Habermasiana à Eugenia Liberal”. Ethic@, 4(3), 2005, Florianópolis, p. 301-377.

FENTON, Elisabeth. "Liberal Eugenics and Human Nature: Against Habermas". Hastings Center Report, 36(6), 2006, p. 35-42.

FUKUYAMA, Francis. Our Posthuman Future: Consequences of the Biotechnology Revolution. New York: Farrar, Straus, and Giroux, 2002.

HABERMAS, Jürgen. O Futuro da Natureza Humana: a caminho de uma eugenia liberal? Trad. Karina Jannini, São Paulo: Martins Fontes, 2004.

HARE, Richard M. "Health". In: Essays on Bioethics. Oxford: Oxford University Press, 1993.

JONAS, Hans. O Princípio Responsabilidade - Ensaio de uma Ética para a Civilização Tecnológica. Trad. Marijane Lisboa e Luiz Barros Montez. Rio de Janeiro: Contraponto/ Editora PUC-Rio, 2006.

KASS, Leon. Life, Liberty and the Defense of Dignity: The Challenge for Bioethics. San Francisco: Encounter Books, 2002.

KITCHER, Philip. "Creating Perfect People". In: HARRIS, John; BURLEY, Justine (Orgs.). A Companion to Genethics. Oxford: Blackwell, 2002, p. 229-42.

NOZICK, Robert. Anarchy, State and Utopia. Oxford: Blackwell, 1974.

PARFIT, Derek. Equality and Priority. Ratio 10 (1997), p. 202-21.

PAULO II, Papa João. Evangelium Vitae - on the Value and Inviolability of Human Life. Vaticano: Libreria Editrice Vaticana, 1995.

RAWLS, John. Uma Teoria da Justiça. Trad. A. Pisseta \& Lenita M. R. Esteves. São Paulo: Martins Fontes, 2002.

RESNIK, David; VORHAUS, Daniel. "Genetic modification and genetic determinism". Philosophy, Ethics, and Humanities in Medicine, London, 1 (2006), p. 01-09. 
L. Frias - Ética e genética: a moral da medicina genética corretiva

SINGER, Peter. Practical Ethics. New York: Cambridge University Press, 1993b.

SINGER, Peter. "Shopping at the Genetic Supermarket". < http://www.utilitarian. net/ singer/by/2003----.htm>, acessado em: 15.02.2007.

STOCK,Gregory. Redesigning Humans: Our Inevitable Genetic Future. Boston: Houghton Mifflin, 2002.

UNITED NATIONS EDUCATIONAL, SCIENTIFIC AND CULTURAL ORGANIZATION.

Universal Declaration on the Human Genome and Human Rights. Paris: UNESCO, 1997.

Recebido em 25 de outubro de 2010.

Aprovado para publicação em 10 de dezembro de 2012. 